\title{
Monitoring and modeling primary production in coastal waters: studies in Massachusetts Bay 1992-1994
}

\author{
John R. Kelly ${ }^{1, *}$, Peter H. Doering ${ }^{2, * *}$ \\ ' 3 Willow Lane, Rye, New Hampshire 03870, USA \\ ${ }^{2}$ Marine Ecosystems Research Laboratory, University of Rhode Island, Narragansett, Rhode Island 02882, USA
}

\begin{abstract}
During 1992-1994, we made shipboard incubations suitable for determining rates of primary production in water from Boston Harbor, Massachusetts Bay, and Cape Cod Bay (Massachusetts, USA). These measurements were part of an extensive baseline monitoring program to characterize water quality prior to diversion of effluent from Boston Harbor directly into Massachusetts Bay via a submarine outfall diffuser. Production $(P)$ was measured using whole-water samples exposed to irradiance (I) levels from $\sim 5$ to $2000 \mu \mathrm{E} \mathrm{m} \mathrm{m}^{-2} \mathrm{~s}^{-1}$ P-I incubations were performed on 6 surveys a year, spaced to capture principal features of the annual production cycle. The number of stations and depths examined varied between years. There were 10 stations and 2 depths sampled in 1992-1993. In 1994, we performed in-depth studies at 2 stations (Boston Harbor's edge and western Massachusetts Bay) by sampling 4 depths. Using depth-intensive 1994 data a simple empirical regression model, using information on chlorophyll biomass, incident daily light, and the depth of the photic zone, predicted integrated primary production rates derived from $P$ - $I$ incubations. The regression model was virtually the same as described for other coastal waters, giving confidence in general use of the model as an extrapolation tool. Using the 1994 -based empirical model, we obtained favorable comparisons with production rates modeled from 1992-1993 P-I incubations. Combining the regression model with data on chlorophyll, light, and the photic zone collected on frequent hydrographic surveys (up to $16 \mathrm{yr}^{-1}$ ), annual primary production was estimated for 1992-1994. Primary production in an intensively studied region of western Massachusetts Bay (21 hydrographic profile stations in an area $\sim 100 \mathrm{~km}^{2}$ ) ranged from 386 to $468 \mathrm{~g} \mathrm{C} \mathrm{m}^{-2} \mathrm{yr}^{-1}$ For a station at the edge of Boston Harbor near Deer Island extrapolations suggested production rates of 263 to $546 \mathrm{~g} \mathrm{C} \mathrm{m}^{-2} \mathrm{yr}^{-1}$ Based on 2 stations in central Cape Cod Bay (1992-1993 only), model extrapolations suggested an annual production of 527 to $613 \mathrm{~g} \mathrm{C} \mathrm{m}^{-2} \mathrm{yr}^{-1}$ Analyses using incubation and modeling results suggested that production variability was strongly related to fluctuations in incident irradiance, especially at daily to seasonal time scales. Chlorophyll variability secondarily influenced production, especially at seasonal to annual time scales. Finally, we provide a case where equivalent production was achieved in environments with contrasting water quality (nutrient and chlorophyll concentrations) because of variations in the depth of the photic zone (controlled by both chlorophyll and non-chlorophyll turbidity). Comparative analyses showed that our study estimates of primary production were consistent with the literature on nutrient-rich shelf environments. In conclusion, our study validated an empirical modeling approach to determining primary production in coastal marine waters.
\end{abstract}

KEY WORDS: Primary production - Monitoring - Modeling Massachusetts Bay - Boston Harbor

\section{INTRODUCTION}

Boston Harbor, Massachusetts Bay and Cape Cod Bay (Massachusetts, USA) are adjacent estuarine and shallow shelf ecosystems that are hydrodynamically

\footnotetext{
-E-mail: rkelly1776@aol.com

- Present address: South Florida Water Management District,

3301 Gun ClubRd, West Palm Beach, Florida 334 16-4680,USA
}

linked. The region is of special interest because Boston Harbor presently exports most of its nutrient input to western Massachusetts Bay (Kelly 1993, 1997) and because the fundamental nature of this estuary-shelf nutrient coupling is scheduled for an abrupt change. Effluent discharge which now provides most of thenutrient input into the Harbor will, in the future, be diverted directly to western Massachusetts Bay via a submarine outfall located about $15 \mathrm{~km}$ offshore in shelf water $-32 \mathrm{~m}$ 
deep. Related to the planned effluent diversion, an extensive baseline water column monitoring data set (cf. Kelly \& Turner 1995a, b) has been collected since 1992 for the Massachusetts Water Resources Authority (MWRA). This paper summarizes results from measurements and modeling of primary production made during 1992-1994 in Massachusetts Bay and Boston Harbor (and to a more limited extent in Cape Cod Bay).

Effective monitoring involves consideration of many issues, including how to measure/model at scales that provide information appropriate for the ecosystem being examined, with designs that are also costefficient. With respect to primary production, scale and extrapolation are important issues because there is high spatio-temporal variability in the environment, but one usually makes detailed measurements by incubating a small volume of captured water and then models the data in one of a variety of ways to calculate integrated primary production. This issue has been addressed through model formulations since the middle of this century (Ryther \& Yentsch 1957). More recently, Cole \& Cloern (1987), and subsequently Keller (1988), essentially followed the Ryther \& Yentsch approach to successfully relate rates of integrated water column production (measured and modeled using bottle incubations) to a composite parameter, $B Z_{\mathrm{p}} I_{0}$, where $B=$ the average chlorophyll concentration $\left(\mu \mathrm{g} \mathrm{l}^{-1}\right)$ in the photic zone, $Z_{\mathrm{p}}=$ the depth of the photic zone $(m)$, and $I_{0}=$ the daily incident photosynthetically active radiation (PAR) to the water surface $\left(E \mathrm{~m}^{-2} \mathrm{~d}^{-1}\right)$. The approach provides a simple empirical regression model which, if validated for a given system, provides a means of extrapolating results over space and time by using data easily measured on standard hydrographic surveys.

The objectives of this paper are (1) to provide estimates of annual primary production for western Massachusetts Bay using incubation measurement results and modeling, (2) to relate production rates to the composite variable $\left(B Z_{p} I_{0}\right)$ and compare results with previous empirical relationships, (3) to use the model approach to examine factors influencing rates of primary production, and (4) to compare estimates of production in the study region to other coastal waters.

\section{METHODS}

Field procedures. P-I incubation studies were conducted during 1992-1994 as a part of broader baseline water quality monitoring surveys. Each year, minor modifications were made in measurements and number of stations. There were a total of 14 hydrographic/ nutrient surveys in 1992 and 16 surveys in 1993 and 1994. A series of comprehensive reports on water col- umn monitoring are published in a technical report series publicly available (see 'Acknowledgements'). Standard measurements for profiling the water column included in situ sensing of conductivity, temperature, dissolved oxygen, beam transmissometry, fluorescence, and photosynthetically active irradiance; discrete bottle measurements for organic and inorganic carbon and nutrients, chlorophyll, suspended solids, and phytoplankton species; and vertical-oblique tows for zooplankton species. In situ fluorescence was postsurvey calibrated by regression against chlorophyll concentration (in vitro, after extraction in acetone; see Parsons et al. 1984) determined from discrete samples The average fluorescence-chlorophyll regression $\mathrm{R}^{2}$ value was 0.7 for 16 surveys; the dynamic range in chlorophyll concentration was low $\left(\sim 2 \mu \mathrm{g} \mathrm{l}^{-1}\right)$ in the 4 surveys with lowest $R^{2}$ values. Except for a brief period early in 1992, when light profiles were measured with a Licor cosine sensor, light readings were made using a Biospherical QSP-200AL underwater $(4 \pi)$ sensor mounted on the top of the hydrocast rosette and a Biospherical QSR-240 cosine sensor for simultaneous ondeck irradiance measurements of incident light.

1994 studies: The 1994 data set forms a principal focus for the summary of water column production considered in this paper. Fig 1 shows the location of all water-quality sampling stations for 1994 ; $P$ - $I$ incubations were done at 2 of these stations. Stn F23P is at the edge of Boston Harbor near present MWRA effluent discharge. Stn N16P is in the middle of a sampling region referred to as the 'nearfield' and is located close to the eastern end of a $2 \mathrm{~km}$ long diffuser track that will discharge MWRA effluent into western Massachusetts Bay bottom water in the future. For productivity, these 2 stations were sampled on $1 \mathrm{~d}$ in February. For each of 5 other surveys (March, April, June, August, October), the stations were sampled on 2 separate days. The 6 surveys covered the entire sampling region (Fig. 1). Ten additional hydrographic/nutrient surveys in 1994 sampled only the 21 nearfield stations (Fig. 1); during June to October, surveys were roughly bi-weekly.

$P-I$ incubations in 1994 used the ${ }^{14} \mathrm{C}$ method of Strickland \& Parsons (1972) as practiced at the Marine Ecosystems Research Laboratory (MERL) at the University of Rhode Island. For samples taken at 4 depths, ${ }^{14} \mathrm{C}$ primary production was measured by exposing samples to a light gradient using an on-deck incubation box with temperature control and artificial illumination ( $250 \mathrm{~W}$ metal halide lamp). The annual temperature range in the Bay surface water is about 1 to $20^{\circ} \mathrm{C}$. Incubation temperatures were maintained within $\sim 3^{\circ} \mathrm{C}$ of conditions in situ; when thermally stratified in summer, this required one incubator set for temperatures in the surface mixed layer samples and one incubator set for temperatures at or near a subsurface chloro- 
Fig. 1 Water quality sampling stations in 1994. A grid of 21 stations labeled ' $N$ ' were in the 'nearfieid' region in western Massachusetts Bay. 'Farfield' stations labeled ' $F$ ' were located in Boston Harbor, other parts of Massachusetts Bay, and Cape Cod Bay. The hydrographic and nutrient sampling statıon design was slightly different during 1992-1993, but all stations labeled ' $\mathrm{P}$ ' were sampled throughout the period. Productivity was measured at these 10 ' $P$ ' stations during 1992-1993, but only at Stns F23P and N16P during 1994. Note that the $40 \mathrm{~m}$ bathymetric contour is shown and this reveals Stellwagen Bank, a submarine shoal which forms part of the boundary between Massachusetts Bay and the Gulf of Maine

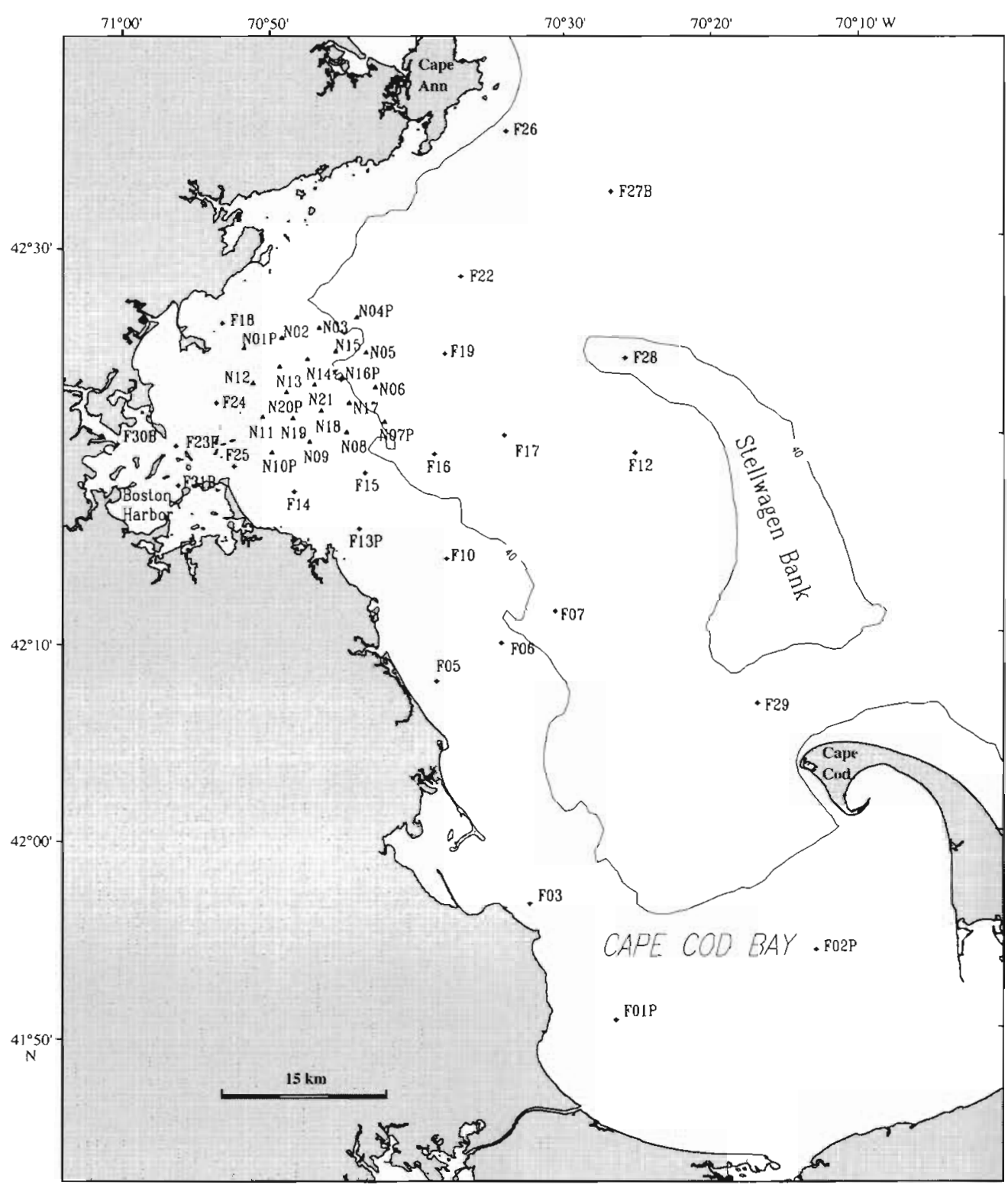

phyll maximum in the upper pycnocline. For each sample depth, fifteen $300 \mathrm{ml}$ BOD (biological oxygen demand) bottles were inoculated with $2.5 \mu \mathrm{Ci}$ of ${ }^{14} \mathrm{C}$ sodium bicarbonate. Three bottles were incubated in the dark. The remaining 12 bottles were exposed to irradiance levels ranging from $\sim 5$ to $2000 \mu \mathrm{E} \mathrm{m}^{-2} \mathrm{~s}^{-1}$. Samples for dissolved inorganic carbon (DIC) were taken on each production-sample hydrocast and used in calculations (Strickland \& Parsons 1972).

1992 and 1993 studies: In 1992 and 1993, production was estimated for 10 stations on 6 surveys in the same months as 1994. Stations (see Fig. 1) included the Harbor-edge and coastal region (F23P and F13P), the nearfield region (N01P, N04P, N07P, N10P, N16P, and N2OP), and Cape Cod Bay (F01P and F02P). In contrast to 1994 measurements, samples were incubated from only 2 depths: near-surface and mid-depth (the subsurface chlorophyll maximum if present). The same basic P.I incubation methods were used throughout $1992-$ 1994, but in 1992, rather than the ${ }^{14} \mathrm{C}$ technique used in 1993-1994, we used the oxygen light-dark technique with a precise autotitration method (Strickland \& Parsons 1972, Oudot et al. 1988).

Analyses. A principal focus is the depth-intensive series of P-I measurements made in 1994; from modeling we also develop estimates of production in previous years and compare them to measurements in those years. For modeling and comparisons, we used various statistical techniques including regression analysis and inference tests that are available on standard software packages (SAS 1988, Borland 1993). 
The following briefly describes procedures for calculating integrated primary production for the 1994 data. Any significant differences in data treatment for 1992 and 1993 not detailed here are described when comparing results in our later discussion. The data for light bottles were first corrected by subtracting uptake measured in dark bottles. The dark-bottle uptake was calculated as the mean of the 3 dark bottles, excluding samples where a value was an outlier, as determined by statistical testing using the Dixon Criterion ( $\mathrm{Na}$ trella 1963)

Dark-corrected values were normalized to measured chlorophyll a (chl a) at the sample depth from which incubation water was taken. A sequence of 2 models was used to fit the incubation data. The first model fit 3 parameters, including a photoinhibition term, and followed the Platt et al. (1980) model to predict net production as

$$
P_{B}=P_{S B}\left(1-e^{-d}\right) e^{-b}
$$

where $P_{B}=$ production (chlorophyll-normalized), $P_{S B}=$ theoretical maximum production (chlorophyll-normalized) without photoinhibition, $a=\alpha I / P_{S B}, b=\beta I / P_{S B} \alpha=$ initial slope of the $P$ - $I$ curve [units of $\left(\mu \mathrm{g} C \mu \mathrm{g}\right.$ chl $a^{-1}$

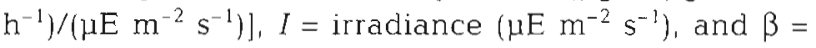
photoinhibition term (same units as $\alpha$ ).

The parameters were fit simultaneously by least squares using the NLIN procedure in SAS (1988) for each incubation series that measured paired $P_{B}$ and irradiance. Fitting was accomplished where parameters were estimated if, within 50 iterations, the model converged on a suitable simultaneous fit (SAS 1988). A derivative-free method was used that compares favorably with methods using partial derivatives (Frenette et al. 1993). If the 3-parameter model (Platt et al. 1980) fitting did not converge on a fit, a 2-parameter model without photoinhibition (Webb et al. 1974) was used, as recommended by Frenette et al. (1993). From the model

$$
P_{B}=P_{\max }\left[1-\mathrm{e}^{\left(-\alpha / / P_{\max }\right)}\right]
$$

where $P_{\max }=$ light-saturated maximal productivity and $\alpha=$ the initial slope for the curve where productivity is proportional to light intensity $(I)$.

$P_{S B}$ must be converted to $P_{\max }$ (the 'assimilation number'; cf. Platt et al. 1980, Falkowski 1981) to make a direct comparison of this parameter between models. For 1992 data, we had followed a convention prior to Frenette et al. (1993), which was to use a hyperbolic tangent model of Platt \& Jassby (1976). Use of as little as 12 observations to model a $P$-I curve can still result in near-optimum error in parameter estimation (cf. Zimmerman et al. 1987). However, our economic design with only 12 observations yielded more precise estimates of $P_{\max }$ than $\alpha$.

For each station profile, an extinction coefficient $(k)$ was determined by regressing $\ln \left(I_{z} / I_{0}\right)$ versus depth, where $I_{0}$ is the deck cell irradiance measured simultaneously with the irradiance at depth $z\left(I_{z}\right)$ and the slope of the regression line estimates $k$. Within an extended survey, $P-I$ incubations were performed on different days. Instead of using day-specific light conditions to model integrated production we standardized conditions for each survey by using the average ( 2 to 5 survey days) incident irradiance $\left(I_{0}\right)$ measured by the deck cell during midday $(10: 00$ to $14: 00 \mathrm{~h})$ to produce an average midday light profile for each station by the equation $I_{0}=I_{z} \mathrm{e}^{-k z}$. At midday, we assumed low reflectance loss and did not further correct $I_{0 i}$ this may introduce minor error but conversion to daily values (below) is likely the largest source of uncertainty. Average midday $I_{z}$ was calculated for each $0.5 \mathrm{~m}$ depth interval from the surface to the base of the photic zone $\left(0.5 \% I_{0}\right)$. We used the $0.5 \%$ level, not a $1 \%$ level since there were initial concerns that a subsurface chlorophyll maximum was productive at depths below the $1 \%$ light level; comparisons to calculations using a $1 \%$ level are provided in the discussion. Chl a concentrations (estimated from in situ fluorescence) were also summarized for each $0.5 \mathrm{~m}$ depth interval. Volumetric production rates were then calculated for each interval using the average midday $I_{z}$ chl $a_{1}$ and the appropriate $P$-I curve determined from incubations. $P$ - $I$ curves from 4 different depths were composited to calculate inte-

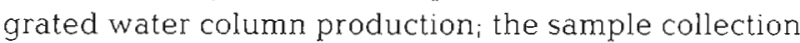
depth served as the midpoint of the depth interval over which each $P$-I curve was applied. The resulting composite $P$ profile was summed to $Z_{0.5 \% I_{0}}$ and converted to $\mathrm{m}^{-2}$ to yield integrated production at midday. Midday hourly $P$ rates were converted to full day rates through multiplication by 7 (Vollenweider 1966). An uncertainty on the order of $\pm 10 \%$ has been calculated for this conversion (Vollenweider 1966); recently, Oviatt et al. (1986) validated the conversion factor for enriched estuarine conditions similar to those in Boston Harbor and western Massachusetts Bay. For 1992 and 1993 P-I incubation results presented in this paper, we used the average of integrated water column rates independently calculated from the 2 incubated samples at each station and did not attempt depthcompositing like that used for 1994 data.

\section{RESULTS AND DISCUSSION}

\section{Production measurement and modeling in 1994}

\section{$P-I$ incubations}

The frequency distribution for $P_{\max }$ modeled from incubations in $1994(\mathrm{n}=88)$ shows that $62 \%$ of the estimates were $\leq 8 \mu \mathrm{g} C \mu \mathrm{g} \mathrm{chl} a^{-1} \mathrm{~h}^{-1}$ and $83 \%$ were 


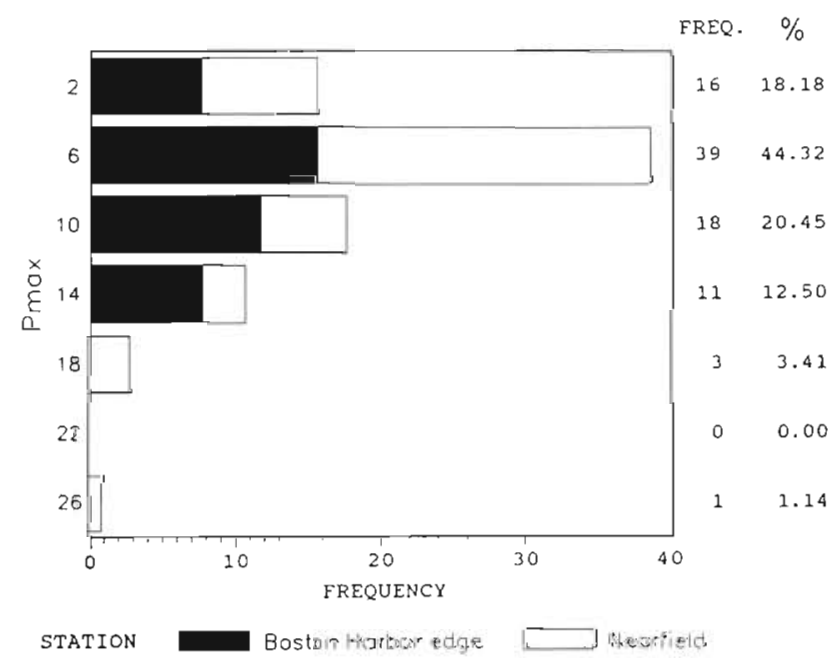

Fig. 2. Frequency distribution for $P_{\max }$ values (units of $\mu \mathrm{g} C \mu \mathrm{g}$ chl $a^{-1} \mathrm{~h}^{-1}$ ) from all 88 modeled $P$ - $I$ curves for Stns F23P (Boston Harbor edge) and N16P (nearfield) durng 1994. A theoretical maximum for $P_{\text {max }}$ is 25 (Falkowski 1981)

$\leq 12 \mu \mathrm{gC} \mu \mathrm{g} \mathrm{Chl} a^{-1} \mathrm{~h}^{-1}$ (Fig. 2). For the entire year, the mean $P_{\max }$ was similar at the 2 stations, 7 to $8 \mu \mathrm{g} \mathrm{C} \mu \mathrm{g}$ chl $a^{-1} \mathrm{~h}^{-1}$; the median $P_{\max }$ was similar to the mean at Stn F23P (7.4), but was slightly lower at Stn N16P (5.7).

There was considerable variability in $P_{\max }$ between station occupations on 2 different days within a survey and over depth within a given day. For example, during summer stratified conditions (e.g. June to August), P-I curves often showed a decrease in $P_{\max }$ between surface and deep samples; a similar trend has been noted in other areas and is sometimes ascribed to photoadaptation (e.g. Falkowski 1981). In spite of daily variability, there were seasonal trends in $P_{\text {max }}$ at the 2 stations. For example, data for Stn F23P showed a progressive increase from winter ( $P_{\max } \approx 2$ in February) to fall $\left(P_{\max }=11\right.$ to 14 in October $)$. In contrast, peaks in $P_{\max }(>10)$ at Stn N16P occurred in early spring (March) and summer (June) and values were in the general range of 2 to 7 at other times.

The frequency distribution for $\alpha$ s modeled from incubations in $1994(n=88)$ shows that $78 \%$ of the estimates were $\leq 0.1$ ( $\left.\mu \mathrm{g} \mathrm{C} \mu \mathrm{g} \mathrm{chl} a^{-1} \mathrm{~h}^{-1}\right) /\left(\mu \mathrm{E} \mathrm{m}^{-2} \mathrm{~s}^{-1}\right)$ (Fig. 3). High $\alpha s(>0.1)$ were often obtained in incubations of near-surface water; there were more cases $(n=$ 13) of high $\alpha$ at Stn N16P than there were at Stn F23P $(\mathrm{n}=5)$.

\section{Integrated ${ }^{14} \mathrm{C}$ production rates at the two stations}

Fig. 4 summarizes integrated rates from depth-composited calculations for all measurements and shows the frequency distribution of daily production rates for 1994. Rates ranged from a low of $157 \mathrm{mg} \mathrm{C} \mathrm{m} \mathrm{m}^{-2}$

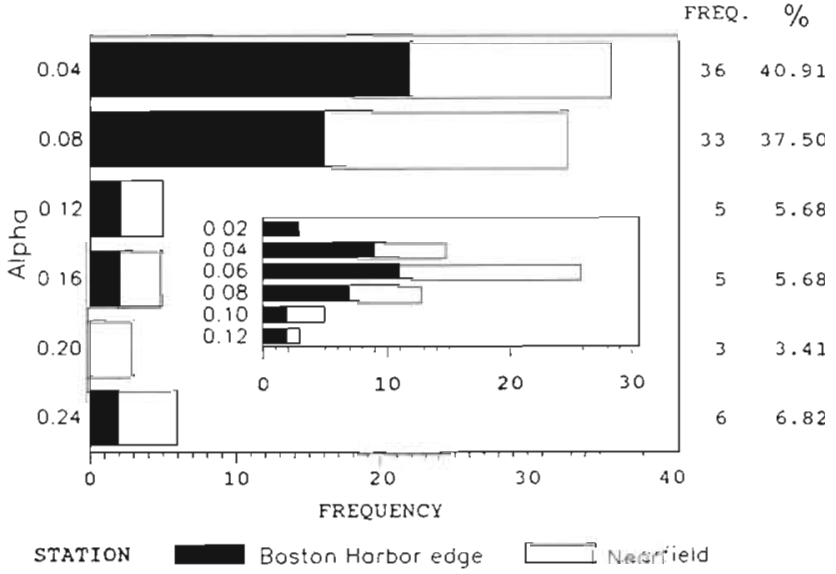

Fig. 3. Frequency distribution for $\alpha$ values [units of ( $\mu \mathrm{g} C \mu \mathrm{g}$ chl $\left.\left.a^{-1} h^{-1}\right) /\left(\mu E \mathrm{~m}^{-2} \mathrm{~s}^{-1}\right)\right]$ from all 88 modeled $P$ - $/$ curves for Stns F23P (Boston Harbor edge) and N16P (nearfield) during 1994. A theoretical maximum for $\alpha$ is 0.1 to 0.115 as expressed in our units. The insert shows the frequency distribution of $\alpha$ for a restricted subset of the data $(n=65)$ that excluded poor model fits (see discussion)
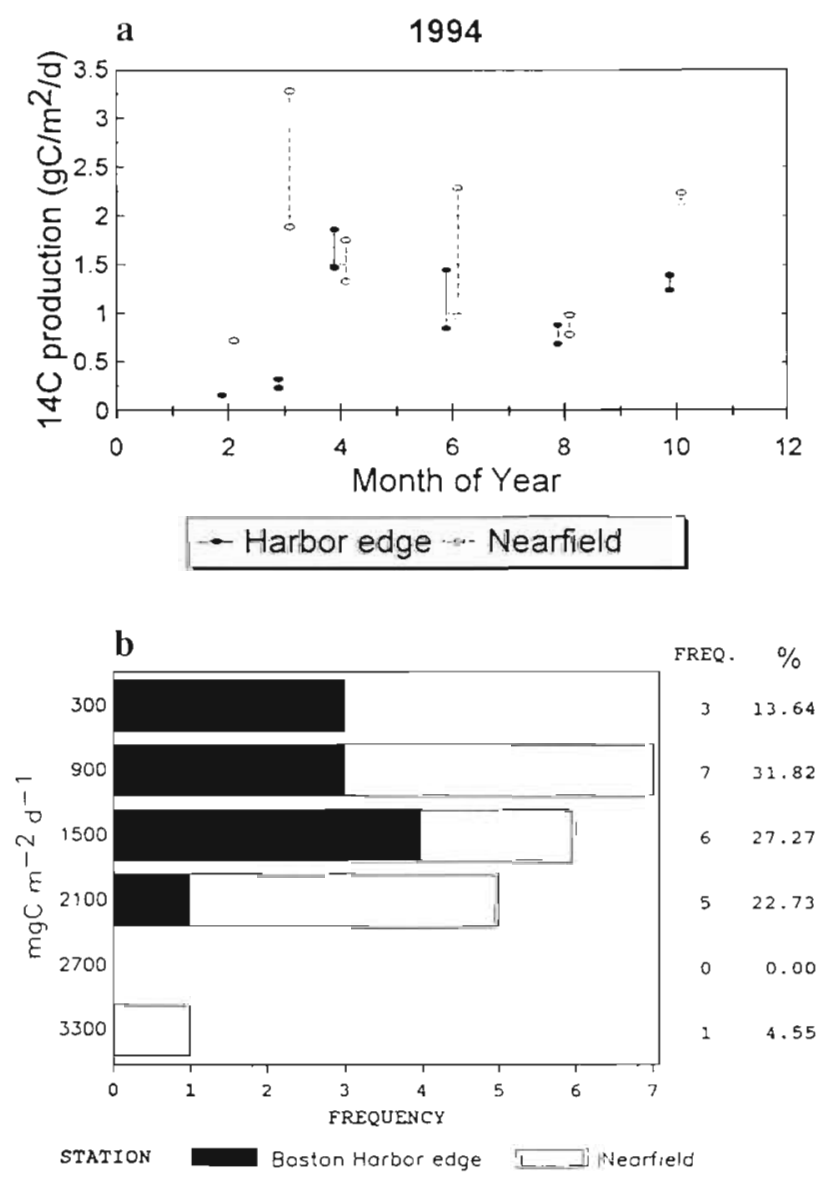

Fig. 4. Production during 1994 for Stns F23P (Harbor edge) and N16P (nearfield). (a) Replicate measurements within a survey were completed in all months except February.

(b) Frequency distribution of production $(n=22)$ 
$\mathrm{d}^{-1}$ at $\operatorname{Stn}$ F23P in February to a high of $3275 \mathrm{mg} \mathrm{C}$ $\mathrm{m}^{-2} \mathrm{~d}^{-1}$ at Stn N16P in March. The mean rate was $1.3 \mathrm{~g} \mathrm{C} \mathrm{m}^{-2} \mathrm{~d}^{-1}(\mathrm{n}=22)$. On average, repeated measurements at a station within days of each other yielded rates within $25 \%$ of each other. However, within-survey variability $\geq 50 \%$ was noted in 3 cases: Stn N16P in March and June, and Stn F23P in June (Fig. 4). In each of these 3 cases, the variability was due to marked differences in $P-I$ curves, not daily chlorophyll fluctuations. Average production rates were significantly lower (2-sample t-test, $\mathrm{p}<0.03$ ) at Stn F23P $\left(0.89 \mathrm{~g} \mathrm{C} \mathrm{m}^{-2} \mathrm{~d}^{-1}\right)$ than at Stn N16P (1.6 $\mathrm{g} \mathrm{C}$ $\mathrm{m}^{-2} \mathrm{~d}^{-1}$, or $1.4 \mathrm{~g} \mathrm{C} \mathrm{m}^{-2} \mathrm{~d}^{-1}$ with the 2 high points of March/June omitted), in spite of significantly higher nutrient concentrations (average annual DIN was $\sim 10 \mu \mathrm{M}$ at F23P versus $-3.5 \mu \mathrm{M}$ at N16P; Kelly 1997). The average photic zone chlorophyll concentrations were similar at the 2 stations $\left(1.91\right.$ vs $2.07 \mu \mathrm{g} \mathrm{l}^{-1}$ at Stns F23P and N16P, respectively). Because of higher inshore turbidity, the average depth of the photic zone was $<15 \mathrm{~m}$ at Stn F23P, compared to $\sim 27 \mathrm{~m}$ at Stn N16P. Therefore, the average photic zone chlorophyll (concentration $\times$ depth $=\mathrm{mg} \mathrm{m}^{-2}$ ) at Stn F23P $\left(27.7 \mathrm{mg} \mathrm{m}^{-2}\right)$ was much lower than at Stn N16P (53.3 $\left.\mathrm{mg} \mathrm{m}^{-2}\right)_{\text {i }}$ this difference may account for much of the difference in production, as is next examined in the empirical model development.

\section{Modeling depth-integrated production}

To develop the composite $B Z_{\mathrm{p}} I_{0}$ parameter of Cole \& Cloern (1987) and Keller (1988), B (photic chlorophyll concentration) and $Z_{\mathrm{p}}$ (photic depth) were readily available from each station profile and the extinction coefficient modeling To derive a daily $I_{0}$, we integrated values from the deck cell readings at the set of station sampling that was typically made from approximately dawn to dusk.

There was a significant relationship between integrated production rates and $B Z_{p} I_{0}$ for the 22 data points for 1994 (Fig. 5a). Two points were above the main trend - the high production estimates for N16P in March and June that were mentioned above in the context of within-survey variability. With or without these points, a linear correlation was significant $\left[R^{2}=\right.$ $0.53, \mathrm{n}=22$ (with); vs $\mathrm{R}^{2}=0.80, \mathrm{n}=20$ (without)]. A functional regression (Ricker 1973) for all points provided the following regression model:

$$
Y=0.61 X-94
$$

Production was calculated using a survey-specific $I_{0}$ (not day-specific). Using replicate measurements for each station during a survey, we developed a regression model using survey averages for each station

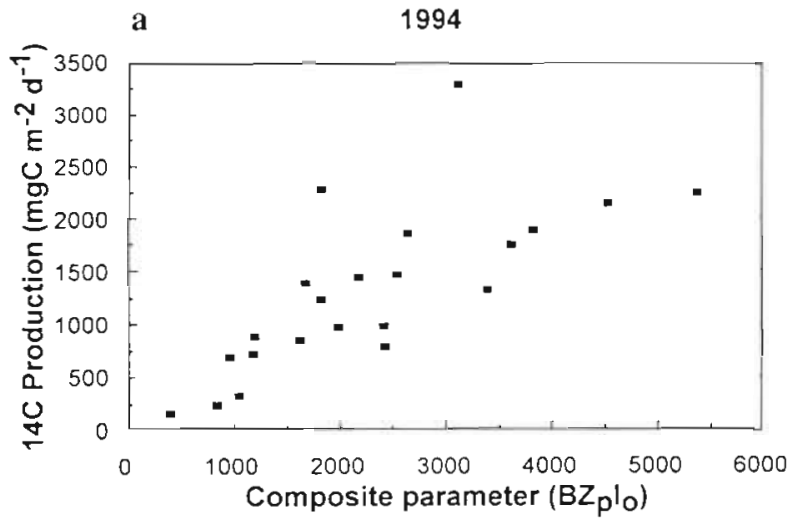

b

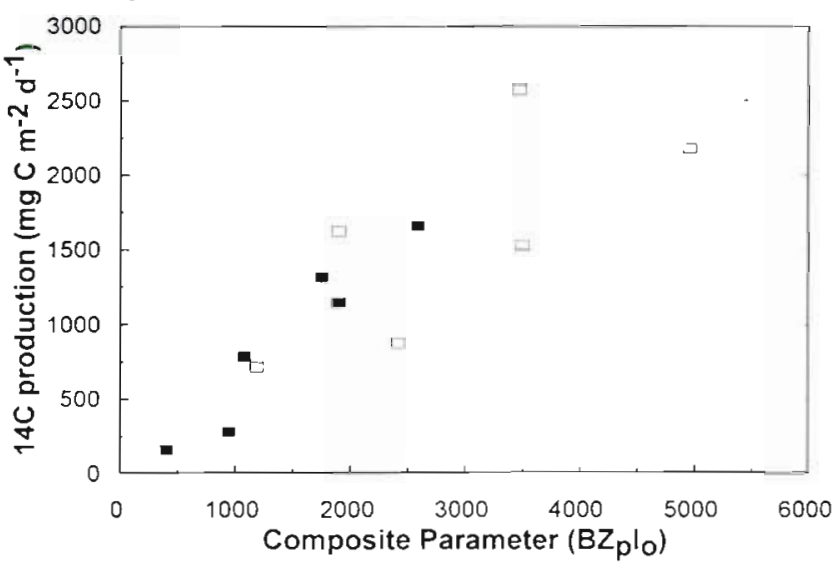

Harbor edge $\square$ Nearfield

Fig. 5. (a) Empirical model for production based on 22 measurements in 1994. (b) Empirical model for production based on survey averages at stations F23P (Harbor edge) and N16P (nearfield) during 1994

(Fig. 5b). Again, a functional regression provided a significant model:

$$
Y=0.56 X+20 \quad\left(\mathrm{R}^{2}=0.73, \mathrm{n}=12\right)
$$

A common formulation for the 2 stations (Eq. 2) was appropriate. Analysis of covariance (Snedecor \& Cochran 1967) demonstrated that the 2 stations did not have significantly different production- $B Z_{\mathrm{p}} I_{0}$ slopes ( $p>0.99$ ) even though production at Stn N16P was significantly higher on average $(p<0.02)$.

Annual production in western Massachusetts Bay in 1994

Measurements of $B, Z_{\mathrm{p}}$, and $I_{0}$ were available from surveys at $\operatorname{Stn}$ N16P for 28 individual days (sometimes 3 separate days within a given survey), providing very extensive coverage of the year Using Eq. (2) we calculated production at Stn N16P for each of these $28 \mathrm{~d}$ 
(Fig. 6). The $B Z_{p} I_{0}$ model here used a day-specific $I_{0}$, whereas measurements used a survey-average $I_{0}$. Subsequently, modeled rates often show high short-term variability when 3 near-consecutive days were surveyed; primarily, variability is driven by sharp fluctuations in light (e.g. cloudy vs sunny days), although a portion is also due to daily variations in measured chlorophyll.

The $B Z_{\mathrm{p}} I_{0}$ model was also applied at a larger scale for the purpose of estimating annual production for an entire nearfield region $\left(\sim 100 \mathrm{~km}^{2}\right)$ surrounding the future offshore outfall, which has been a focus for MWRA monitoring. For each of 16 surveys in 1994, 21 stations in this region had suitable data for use in the $B Z_{\mathrm{p}} I_{0}$ model. For each survey, the average $B(\mathrm{n}=21$, summarized from $0.5 \mathrm{~m}$ bin-averaged data to the limit of the photic zone), $Z_{\mathrm{p}}(\mathrm{n}=21)$, and $I_{0}(1$ to $3 \mathrm{~d})$ were calculated. Resultant projections of integrated production are shown in Fig. 7. Results are similar to those for Stn N16P (Fig. 6) because that station is near the center of the region and often represents a near-average condition. Assuming the winter, low productivity, months not sampled had daily production averaging $250 \mathrm{mg} \mathrm{C} \mathrm{m} \mathrm{m}^{-2} \mathrm{~d}^{-1}$, annual integration of the $B Z_{\mathrm{p}} I_{0}$ model rates estimate the nearfield's primary production as $468 \mathrm{~g} \mathrm{C} \mathrm{m}^{-2} \mathrm{yr}^{-1}$. The late spring ( Day 150, post-bloom) model projection may be overestimated considering that nutrients were virtually depleted at this time (Kelly \& Turner 1995b); omission of this late spring peak would reduce the annual estimate about $7 \%$, to $435 \mathrm{~g} \mathrm{C} \mathrm{m}^{-2} \mathrm{yr}^{-1}$.

For the Harbor station, we do not have 16-survey data for modeling production throughout the year and must extrapolate to annual values from measurements made only 6 times. From the nearfield results, the average daily rate from the annual integration based on modeling results was $1.3 \mathrm{~g} \mathrm{C} \mathrm{m}^{-2} \mathrm{~d}^{-1}$, a value that is about $81 \%$ of the average based on 6 surveys at Stn N16P. Assuming this $81 \%$ factor can be applied in extrapolating the set of 6 measurements at Stn F23P to a full year, the resulting annual production at the edge of the Harbor is estimated as $263 \mathrm{~g} \mathrm{C} \mathrm{m}^{-2} \mathrm{yr}^{-1}$.

\section{Empirical production model for 1994}

\section{Comparison to previous formulations}

Cole \& Cloern's (1987) equation for photic zone production $(Y)$ and $B Z_{p} I_{0}(X)$ measurements $(\mathrm{n}=211$, same units as this study) from Puget Sound, New York Bight, South and North San Francisco Bays is:

$$
Y=0.73 X+15 \quad\left(\mathrm{R}^{2}=0.82\right)
$$

Keller (1988) derived a similar equation for measurements ( $n=1010$, same units as this study) from a variety of MERL mesocosm experiments and data for Narragansett Bay (Rhode Island, USA):

$$
Y=0.70 X+220 \quad\left(\mathrm{R}^{2}=0.82\right)
$$

The slope of models for different estuaries and experiments in estuarine/coastal regions varies within a rather small range, about 0.66 to 1.14 , and may be sensitive $( \pm 10 \%)$ to variations in the length of incubation between 4 and $24 \mathrm{~h}$ (Keller 1988).

The ${ }^{14} \mathrm{C}$ technique was used to derive Eqs. (2) to (4), but there were still methodological differences among the set of studies summarized by Cole \& Cloern (1987),

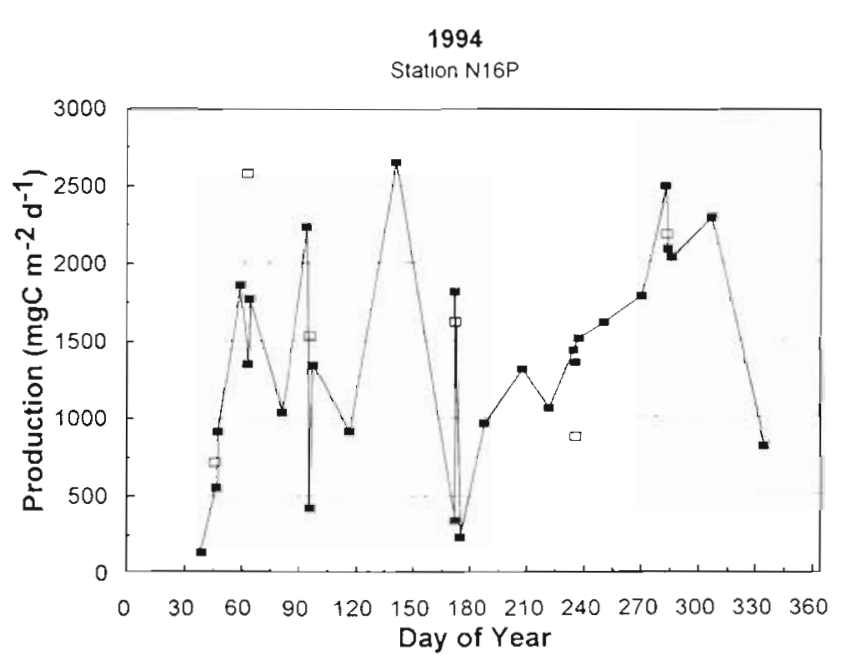

- Empirical model $\square$ Measurement

Fig. 6. Production at Stn N16P during 1994

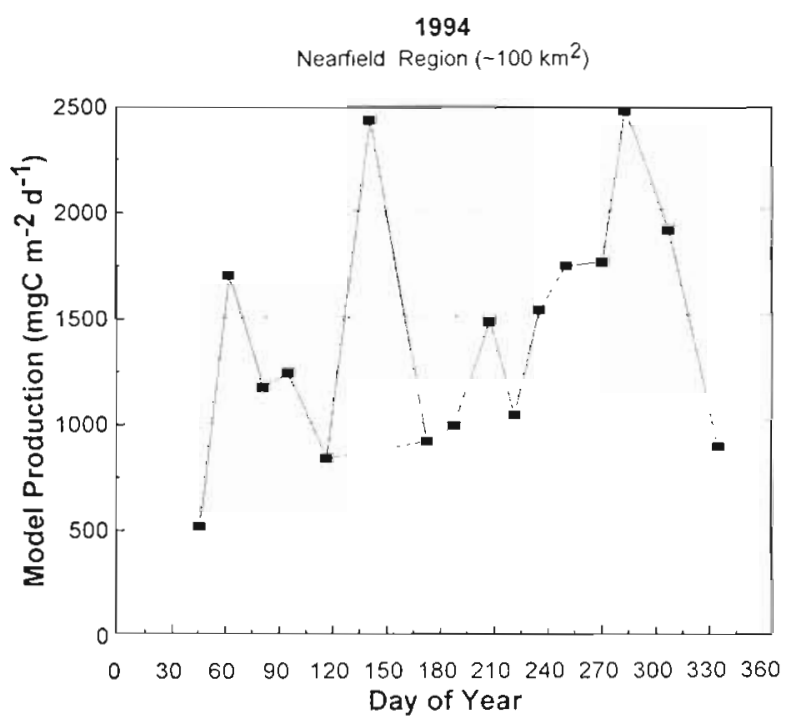

Fig. 7 Model-calculated production in the nearfield region. during 1994 
Keller (1988), and this study. One difference that generically will affect the model's slope is the presumed depth of the photic zone, because this differentially affects the production calculation and the composite parameter $\left(B Z_{\mathrm{p}} I_{0}\right)$. Both Cole \& Cloern (1987) and Keller (1988) used the $1 \%$ PAR level, not the $0.5 \%$ level used in our calculations. Recalculations for all 1994 incubation data using the $1 \%$ light level only lowered integrated production rates an average of $3 \%$ (range $=0$ to $10 \%, \mathrm{n}=22$ ) relative to use of the $0.5 \%$ light level. We also recalculated $B Z_{p} I_{0}$ to the $1 \%$ PAR level for the 1994 data set to enable comparison of regressions from previous studies. The functional regression for survey-averaged data (as with Eq. 2) was significant $\left(R^{2}=0.66, n=12\right)$ and the resulting model was:

$$
Y=0.79 X+285
$$

The intercept of previous predictive regression models has often, but not always, been equal to zero (cf Keller 1988). The value in Eq. (5), though relatively high, has a minor influence on the level of predicted annual production.

For direct comparison to this study, we estimated functional regression slopes (functional regression slope $=$ predictive regression slope/correlation coefficient; see Ricker 1973) for Eqs. (3) and (4) as 0.81 and 0.77 , respectively. The slope of the 1994 Harbor-Bay model is virtually indistinguishable from formulations developed for a variety of other locations and conditions. Thus, our study of stations from Boston Harbor and western Massachusetts Bay shows this region is no exception to a general empirical finding on the relationship between production, biomass, and light (cf. Ryther \& Yentsch 1957, Falkowski 1981, Cole \& Cloern 1987).

\section{Interannual comparisons of measurements and modeling in our study region}

Using the empirical model (Eq. 2) from 1994, production was estimated for 16 surveys of the nearfield in 1993, again using data averaged for all 21 nearfield stations (Fig. 8). Production in 1993 was higher on average than in 1994. Primarily, this occurred because of generally higher summer rates and very high rates (>5 $\mathrm{g} \mathrm{C} \mathrm{m}^{-2} \mathrm{~d}^{-1}$ ) in an immense September-October 1993 bloom of the diatom Asterionellopsis glacialis $\left(\sim 1.2\right.$ to 6.5 million cells $1^{-1}$ and total chl a concentrations averaging $\sim 10$ to $12 \mu \mathrm{g} \mathrm{l}^{-1}$ ). Integration of 1993 model results (Fig. 8) gave an annual nearfield production of $620 \mathrm{~g} \mathrm{C} \mathrm{m}^{-2} \mathrm{yr}^{-1}$, based on an average daily rate of $1.7 \mathrm{~g} \mathrm{C} \mathrm{m}^{-2} \mathrm{~d}^{-1}$.

Also shown in Fig. 8 are the average production rates measured at 6 of the 21 nearfield stations (see 'Meth- ods') on 6 of the 16 surveys in 1993. Model and measurements compare favorably, and the range for 6 measurements encompasses the model result for each comparison. A functional regression of model and measurement yielded a significant relation $\left(R^{2}=0.66\right.$, $n=6)$, in which the slope $( \pm S E)$ was $0.87( \pm 0.25)$ and not different from 1. The model formulated from 1994 data essentially applied without modification to 1993 data.

The model average $\left(1.7 \mathrm{~g} \mathrm{C} \mathrm{m}^{-2} \mathrm{~d}^{-1}\right)$ for 16 nearfield surveys in 1993 was $74 \%$ of the average nearfield rate measured on 6 surveys $\left(2.3 \mathrm{~g} \mathrm{C} \mathrm{m}^{-2} \mathrm{~d}^{-1}\right)$. In 1993, production measurements ( $P$-I incubations) were also made at Stn F23P at Boston Harbor's edge and 2 stations in central Cape Cod Bay on the 6 surveys. Using the mean daily rates, assuming a $74 \%$ factor to convert from 6 measurements to the full annual cycle, production was $486 \mathrm{~g} \mathrm{C} \mathrm{m}^{-2}$ for Stn F23P (mean $=1.8 \mathrm{~g} \mathrm{C} \mathrm{m}^{-2}$ $\mathrm{d}^{-1}, \mathrm{n}=6$ ) and $527 \mathrm{~g} \mathrm{C} \mathrm{m}^{-2}$ for central Cape Cod Bay (mean $=1.95 \mathrm{~g} \mathrm{C} \mathrm{m}^{-2} \mathrm{~d}^{-1}, \mathrm{n}=12$ ).

The modeling exercise was repeated for 1992, again using the 1994 empirical model (Eq. 2). Production was predicted using appropriate data on $B, Z_{\mathrm{p}}$, and $I_{0}$ for 21 nearfield stations gathered on the 11 surveys in 1992 for which suitable data were available (Fig. 9). Integration of 1992 model results gave an annual nearfield production of $386 \mathrm{~g} \mathrm{C} \mathrm{m}^{-2} \mathrm{yr}^{-1}$, based on an average daily rate of $1.06 \mathrm{~g} \mathrm{C} \mathrm{m}^{-2} \mathrm{~d}^{-1}$.

Also shown in Fig. 9 are the average daily rates measured for 6 stations in the nearfield at each of 6 surveys. In this year $P$ - $I$ incubations were oxygen- rather than ${ }^{14} \mathrm{C}$-based and the modeling effort differed slightly from 1993-94; we used a photosynthetic quotient $(P Q)$ of 1 to convert rates shown in Fig. 9 from $\mathrm{O}_{2}$ to $C$. The model underestimated measurements in March 1992, but the comparison of model and mea-

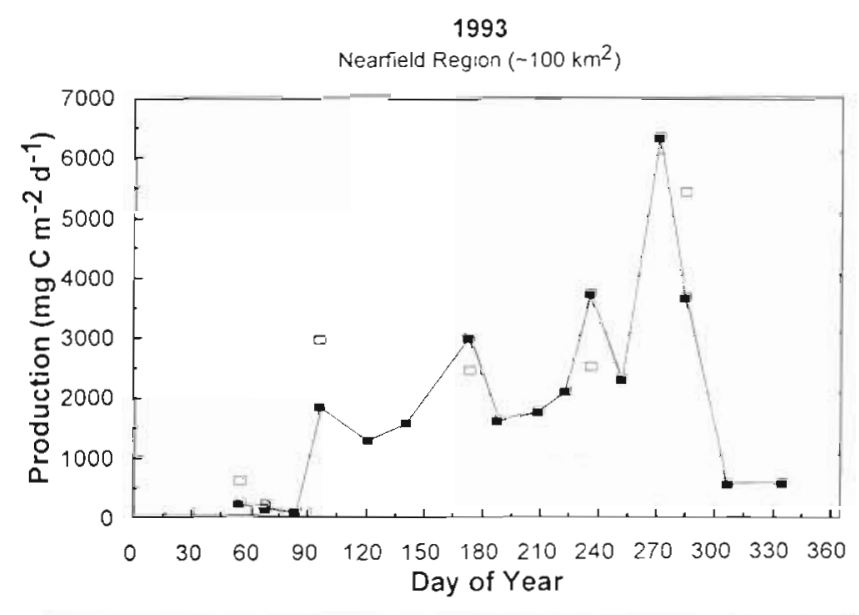

- Empirical model Measurements (6-station mean)

Fig. 8. Production in the nearfield region during 1993 
surement yielded strong correlations $\left(R^{2}=0.46, n=6\right.$; or, omitting the March measurement, $\mathrm{R}^{2}=0.92, \mathrm{n}=5$ ). The respective functional regression slopes $( \pm \mathrm{SE})$ were $1.0( \pm 0.45)(n=6)$ and $1.12( \pm 0.21)(n=5)$.

The regression slope suggests that the model formulated from 1994 data $\left({ }^{14} \mathrm{C}\right.$-based studies) predicts 1992 results based on $\mathrm{O}_{2}$ using a $P Q$ near 1 . This value is a common oceanographic convention (e.g. Parsons et al. 1984), but to some extent may be coincidental; there are complicating physiological, methodological, and modeling factors. In supplemental studies, we made individual measurements of $P_{\max }$ by both $\mathrm{O}_{2}$ and ${ }^{14} \mathrm{C}$ methods; about $50 \%$ of the tests ( $\mathrm{n}=11$ ) gave a $P Q=1$ at saturating light conditions, but the $P Q$ range was wide, 0.7 to 2.7 , like many previous studies (e.g. Oviatt et al. 1986). Moreover, there are numerous reasons that oxygen-based measurements would not directly compare with ${ }^{14} \mathrm{C}$ to provide a phytoplankton $P Q$ (cf. Bender et al. 1987); 2 significant aspects are mentioned. First, oxygen and ${ }^{14} \mathrm{C}$ methods do not measure the same processes - short ${ }^{14} \mathrm{C}$ incubations (hours) such as ours probably approximate gross production (Peterson 1980, Leftley et al. 1983, Davies \& Williams 1984, Bender et al. 1987) whereas oxygen measures net production. Second, for our P-I modeling with $\mathrm{O}_{2}$ we included a fourth model term $(R=$ respiration, a constant). This allowed estimation of the compensation light intensity, where respiration exceeded production and no net production occurred (cf. Jassby \& Platt 1976, Cote \& Platt 1983). Accordingly, depth-integration of production was carried to the compensation depth (net production $\leq 0$ ), rather than to a constant isolume, as with ${ }^{14} \mathrm{C}$. Since the modeled compensation depth was often reached at depths shallower than the $0.5 \%$ light level, the modeling could produce $\mathrm{O}_{2}$-based underestimates of integrated ${ }^{14} \mathrm{C}$ production.

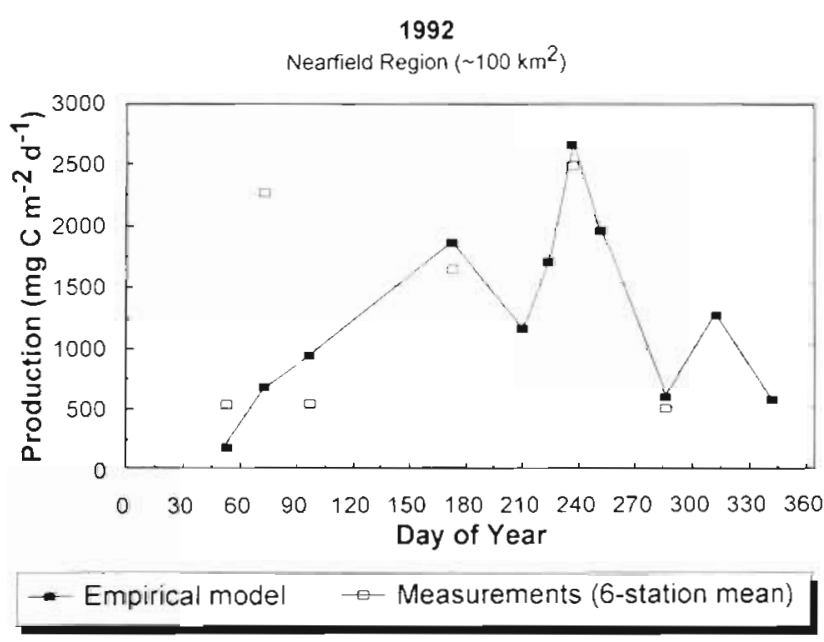

Fig. 9. Production in the nearfield region during 1992
$\mathrm{O}_{2}-\mathrm{C}$ conversion issues notwithstanding, the 1992 measurements were predicted by the $B Z_{p} I_{0}$ model formulated from 1994 data. The average daily rate from 6 station, 6-survey measurements of the nearfield region in 1992 was $1.32 \mathrm{~g} \mathrm{C} \mathrm{m}^{-2} \mathrm{~d}^{-1}(P Q=1)$. The modeled rate for 11 -survey data was $80 \%$ of this, or comparable to previous years (74 to $81 \%$ ). In 1992, Stn F23P and 2 stations in central Cape Cod Bay were sampled for productivity on only 6 surveys. Assuming the $80 \%$ conversion applies to extrapolate the mean daily rates to an annual cycle (as previous years), 1992 annual production was $546 \mathrm{~g} \mathrm{C} \mathrm{m}^{-2}$ for Stn F23P (mean $=1.87 \mathrm{~g} \mathrm{C} \mathrm{m}^{-2}$ $\mathrm{d}^{-1}, \mathrm{n}=6$ ) and $613 \mathrm{~g} \mathrm{C} \mathrm{m}^{-2}$ for central Cape Cod Bay (mean $=2.1 \mathrm{~g} \mathrm{C} \mathrm{m}^{-2} \mathrm{~d}^{-1}, \mathrm{n}=11$ with 1 anomalous point omitted).

\section{Modeling uncertainty and sensitivity analyses}

$$
\text { P-I modeling }
$$

The average \% error (standard error/parameter estimate $\times 100$ ) for all curves described by oxygen changes (1992 stations) was compared with those curves obtained with the ${ }^{14} \mathrm{C}$ technique in 1993 (a comparable sample design with similar numbers of samples to 1992). As expected, ${ }^{14} \mathrm{C}$ was much more precise than oxygen for estimating both $P_{\max }$ and $\alpha$ (cf. Peterson 1980, Leftley et al. 1983). For oxygen in 1992, the error was $36 \%\left(P_{\max }\right)$ and $69 \%(\alpha)$, whereas for ${ }^{14} \mathrm{C}$ in 1993 it was $4 \%\left(P_{\max }\right)$ and $19 \%(\alpha)$. The average $\mathrm{R}^{2}$ for oxygenbased curve fits was 0.7 , whereas it was 0.9 for ${ }^{14} \mathrm{C}$ in 1993. Excluding non-significant fits (or, at $95 \%$ probability, where $R^{2}<0.33$ for $\mathrm{df}=10$ ), oxygen and ${ }^{14} \mathrm{C} \bmod$ eling errors compared more favorably; non-significant fits usually occurred in samples with generally low chlorophyll and low production rates. For either technique, $P_{\max }$ was more precisely estimated than $\alpha$.

In general, $P_{\max }$ values in the range of 2 to 10 are typical of marine studies and our results were similar to representative ranges for other studies (cf. Platt \& Jassby 1976, Falkowski 1981, Malone \& Neale 1981. Laws et al. 1990). Values for marine plankton in batch culture have a wide range ( 1 to 21 ; e.g. Glover 1980) and values have been reported for natural assemblages that approach or exceed 25 (a theoretical maximum; cf. Platt \& Jassby 1976, Falkowski 1981, Malone \& Neale 1981). For all 1992-1994 data, <3\% of the modeled $P-I$ curves $(n=304)$ produced $P_{\max }$ values above a theoretical maximum. By supplemental studies, we determined that neither small sample volumes (10 ml) that were used for chlorophyll analyses nor our standard practice of normalization of ${ }^{14} \mathrm{C}$ rates with the initial chl a concentrations introduced a strong or consistent bias upon $P_{\max }$. We have no reason to suspect 
that our study's $P_{\max }$ values were unusual or poorly fit by modeling.

In contrast to $P_{\text {max }}$ for $1994 P$-I incubations there were some anomalously high $\alpha(>0.1)$ results that exceeded the theoretical limit for $\alpha(0.1$ to 0.115 , expressed in our units; cf. Bannister 1974, Platt \& Jassby 1976, Malone \& Neale 1981). This is not an uncommon result; in practice, experiments often produce some data with as above the theoretical maximum (e.g. Platt \& Jassby 1976, Malone \& Neale 1981). The standard error of the estimate of $\alpha$ generally increased with increasing $\alpha$ and most $P$ - $I$ incubations in 1994 with high $\alpha$ had a low $\mathrm{R}^{2}$ for the $P$ - $I$ model fit. High $\alpha$ values may arise from simultaneous fitting of parameters (e.g. Jassby \& Platt 1976). Re-fitting an $\alpha$. parameter independent of the full P-I model might reduce some high $\alpha \mathrm{s}$, but this approach usually is not recommended (cf. Frenette et al. 1993). Instead, as a sensitivity exercise, we excluded 23 P-I curves where $\mathrm{R}^{2}<0.8$ and/or where $\alpha>0.1$, unless the sample was at a light saturating depth. These criteria left 65 P-I curves from the full data set: $\mathrm{n}=34$ at $\mathrm{Stn}$ F23P and $\mathrm{n}=$ 31 at Stn N16P. The insert in Fig. 3 shows the frequency distribution for the restricted data set. The mean $\alpha$ for the restricted data was similar between stations and at 0.06 was 52 to $60 \%$ of the theoretical limit and $\sim 40 \%$ lower than the mean for the full set. In contrast, the values for $P_{\max }$ for the full set ( $n=88$ ) and the restricted set $(n=65)$ were essentially unchanged ( $<5 \%$ different)

Using the restricted 1994 data set to recalculate production, we again obtained a significant regression of integrated ${ }^{14} \mathrm{C}$ production vs $B Z_{\mathrm{p}} I_{0}\left(\mathrm{R}^{2}=0.77, \mathrm{n}=12\right)$. Compared to the full set, the functional regression slope was 0.51 , or about $10 \%$ lower than Eq. (2), which directly translates to a $10 \%$ decrease in estimates of daily and annual rates. The modest decrease in production compared to the $40 \%$ decrease in $\alpha$ for the restricted data set can be in part explained because most production occurs at light saturation (i.e. at $P_{\max }$ ) near the surface. Additionally, we performed a complimentary exercise using the 1994 data set. The average relative \% error for repeated surface sample incubations at each of the 2 stations on 2 sampling days within a survey $(\mathrm{n}=10)$ was $23 \%$ and $40 \%$ for $P_{\max }$ and $\alpha$, respectively. In contrast, the relative \% error for integrated production rates for the same replicate station pairs ( $\mathrm{n}=10$ ) was substantially lower, $\sim 17 \%$.

These simple analyses suggest that integrated production was not highly sensitive to imprecisions of $\alpha$ in our $P$-I modeling. For surface samples, which constituted most of the poor $P-I$ model fits, light levels were high during midday (>200 $\left.\mu \mathrm{E} \mathrm{m}^{-2} \mathrm{~s}^{-1}\right)$; consequently, the term did not strongly affect the calculated rate because irradiance was near saturating levels.
Implications of the empirical model concept: time-space variability and factors regulating production

In comparisons above, computed relative \% error did not incorporate any day-to-day variation in incident light because a standard light was used in all calculations within each survey. The influence of light fluctuations is next explored separately using the $B Z_{p} I_{0}$ model construct. In practice, the model parameters $B$ and $Z_{\mathrm{p}}$ are not independent - increases in $B$, to a degree, decrease $Z_{p}$ (e.g Bannister 1974). For example, using the nearfield data averaged for each survey in 1994, there was a significant negative linear correlation between $B$ and $Z_{\mathrm{p}}\left(\mathrm{R}^{2}=0.65, \mathrm{n}=16\right)$. Multiplied, the combined term $\left(B Z_{\mathrm{p}}\right)$ calculates photic zone mass of chlorophyll ( $\mathrm{mg} \mathrm{m} \mathrm{m}^{-2}$ ). Fig. 10 displays variations in $B Z_{p}$ and $I_{0}$ for Stn N16P in 1994, along with the model result for production. $I_{0}$ is generally the larger term, but also has the greater range and can experience more rapid and extreme fluctuations when sunny and cloudy days are juxtaposed (see 3-day series near Day 95 and also Day 175). On a daily to weekly basis, variations in incident irradiance were a prime determinant of the level of production, as suggested by the similarly high level of variability in $I_{0}$ and production (Table 1). In contrast, chlorophyll concentrations ( $B Z_{\rho}$ and $B$ terms) were the most variable and similar to production variability at seasonalannual time scales (Table 1). An interpretation from Fig. 10 and Table 1 was that incident light is always a major factor determining production, while fluctua-

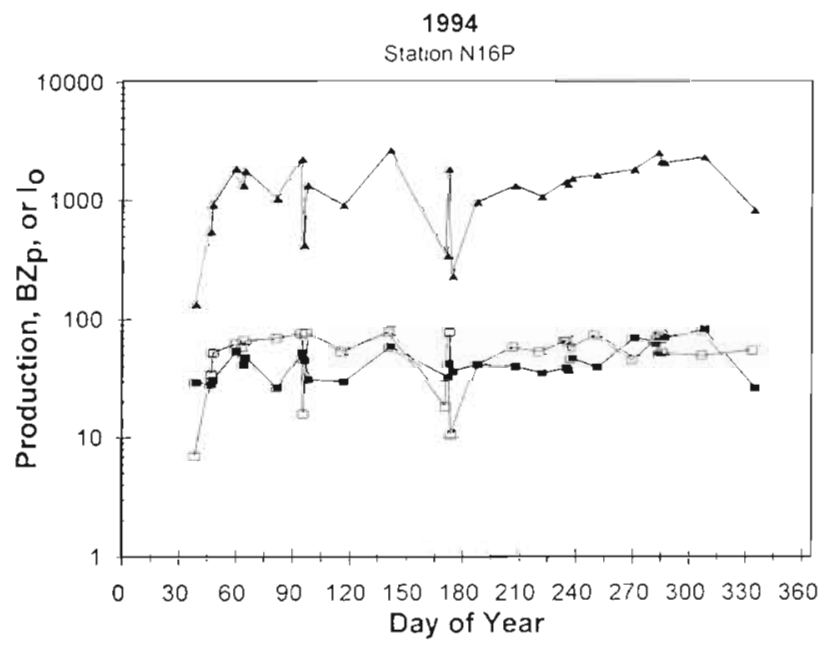

$$
-\operatorname{Prod}\left(\mathrm{mgC} \mathrm{m} \mathrm{m}^{-2} \mathrm{~d}^{-1}\right) \square \mathrm{l}_{0}\left(\mathrm{Em}^{-2} \mathrm{~d}^{-1}\right)-3 z_{\mathrm{p}}\left(\mathrm{mg} \mathrm{Chl} \mathrm{m}^{-2}\right)
$$

Fig 10. Variability in modeled production and the $I_{0}$ and $B Z_{p}$ terms of the empirical model at Stn N16P during 1994. Production is the same as presented in Fig. 6, but is shown on a $\log$ scale 
Table 1. Average relative \% error for production-related variables, summarized at different scales. Data are for measurements at. Stn N16P in 1994. Comparisons are valid across rows, but comparison down columns have different ' $n$ ' and should be made: with caution. Bold entries identify factors with variability similar to production (see text)

\begin{tabular}{|c|c|c|c|c|c|c|}
\hline \multirow[t]{2}{*}{ Data summary } & \multirow[t]{2}{*}{ Relevant time scale } & \multicolumn{5}{|c|}{$\%$ error for: } \\
\hline & & $I_{0}$ & $B$ & $Z_{p}$ & $B Z_{\mathrm{p}}$ & Production (modeled) \\
\hline Paired days of $P$ - $I$ incubations ( $\mathrm{n}=5$ pairs) & -Days & 27 & 10 & 7 & 9 & 33 \\
\hline Sets of $4 \mathrm{~d}$ within 6 major surveys $(n=5$ sets $)$ & Week & 22 & 12 & 6 & 8 & 26 \\
\hline Sets of 8 to $12 \mathrm{~d}$ within 4 seasons ( $\mathrm{n}=4$ sets) & -Season & 10 & 24 & 6 & 19 & 24 \\
\hline Set of $28 \mathrm{~d}$ on 16 surveys $(n=28)$ & -Annual & 6 & 10 & 4 & 6 & 9 \\
\hline
\end{tabular}

tions in chlorophyll have a strong role in establishing seasonal and annual patterns of production in the Harbor-Bay region. Chlorophyll and nitrogen concentrations are strongly related; each parameter exhibits a similar gradient of decreasing concentrations from the Harbor edge into western Massachusetts Bay, reaching 'background' shelfwater levels about $20 \mathrm{~km}$ from the Harbor (Kelly 1997). In essence then, both light and nutrients (see also below) influence production in the region.

Much as daily fluctuations in cloud cover can control production, spatial chlorophyll variability $(B$ and $B Z_{p}$ ) at fine scales (meters to 100 s of meters) in the western Massachusetts Bay area (Fig. 11) will also influence production at a localized scale (e.g. at a fixed sampling station location). The effect of this spatial variability is brought into focus when considering that $P$ - $I$ incubations are done on small volumes $(<1 l)_{i}$ subsequent extrapolation using adequately characterized chlorophyll concentrations in nature are critical assumptions at fine space scales. At broader scales (kilometers and seasons), the influence of chlorophyll variability on integrated production has significance if there are persistent spatial gradients, either in chlorophyll concentrations or the degree of patchiness. To examine this, we looked across a chlorophyll concentration (B) gradient consistently seen across the nearfield region.

The conceptual model is that production $=f\left[I_{0}\left(B Z_{p}\right)\right]$. Each station sampled on a nearfield survey had equal daily light; the effect of $I_{0}$ is thus removed by comparing stations, to ask how the observed gradient from shore relates to production. $B$ and $Z_{\mathrm{p}}$ terms were summarized for a group of 4 stations on the west side of the nearfield, nearer the harbor (Stns N01P, N12, N11, and N10P; Fig. 1), for comparison with 4 stations on the east side, towards the open shelf (stations N04P, N05, N06, N07P; Fig. 1). Statistical tests have shown that these groups of stations differ with respect to their surface chlorophyll concentrations (Kelly \&
Fig. 11. An example of fine-scale spatial variability in chlorophyll concentration as estimated by in situ fluorescence. Data were collected by profiling with an in situ fluorometer oscillating from near-surface to nearbottom at vessel speeds from 4 to 7 knots. From Kelly (1993)

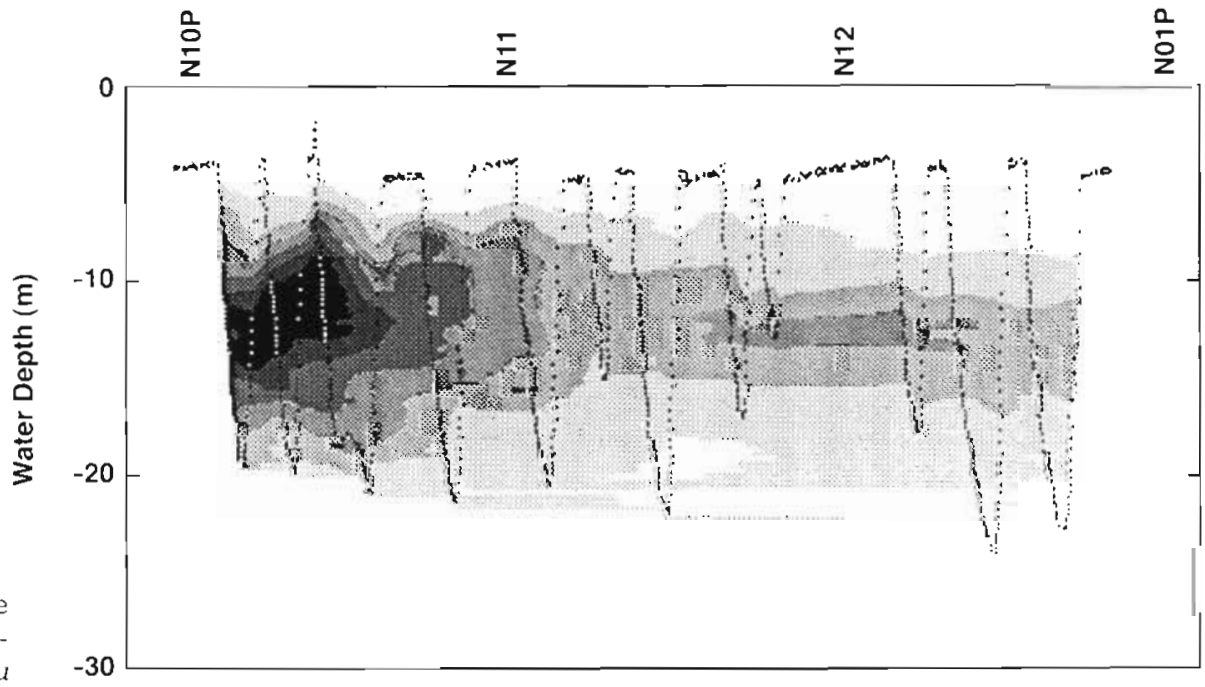

Chlorophyll a $(\mu \mathrm{g} / \mathrm{L})$

$\begin{array}{lllllll}1 & 2 & 3 & 4 & 5 & 6 & 7\end{array}$

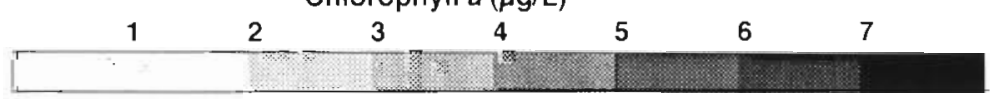


Turner 1995a, b). Westerly chlorophyll enrichment was evident for most of the year (Fig 12) for concentrations averaged over the entire photic zone $(B)$; the west average $=2.5 \mathrm{\mu g} \mathrm{l}^{-1}$ and east average $=2.0 \mu \mathrm{g}$ $\mathrm{I}^{-1}$. In contrast, the east group of stations had a consistently deeper $Z_{p}$ (Fig 12) Interestingly, production (Fig 12) between the groups was within 10 to $15 \%$ (not different by 1 -tailed $t$-test on 16 surveys, $\mathrm{df}=30$, $\mathrm{p}<0.18$ ), because the $B$ and $Z_{\mathrm{p}}$ terms essentially counterbalanced each other. Comparison of production rates measured at the 6 nearfield stations in 1993 and 1992 confirm similar average production across groups of stations in the region (Kelly et al. 1993, Kelly \& Turner 1995a)

Similar production levels may be achieved where roughly constant photic biomass $\left(B Z_{p}\right)$ results from opposing gradients in $B$ and $Z_{\mathrm{p}}$ since $Z_{\mathrm{p}}$ increases at about the pace per kilometer from shore that $B$ decreases. This result may arise from unusual circumstances. The deepening of $Z_{\mathrm{p}}$ was faster than could be predicted from changes in chlorophyll alone [the effect on $k_{r}$ the extinction coefficient, is expected to be

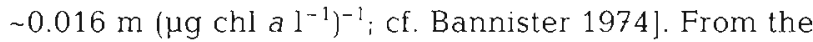
linear relationship between $B$ and $Z_{p}$ (noted above) we estimate an effect on $k$ equivalent to $0.035 \mathrm{~m}(\mu \mathrm{g}$ chl a $\left.1^{-1}\right)^{-1}$. We therefore attribute the deepening in $Z_{\mathrm{p}}$ to approximately equal parts decrease in chlorophyll and non-chlorophyll turbidity from west to east across the nearfield.

\section{4}

West and East Lines of Nearfield

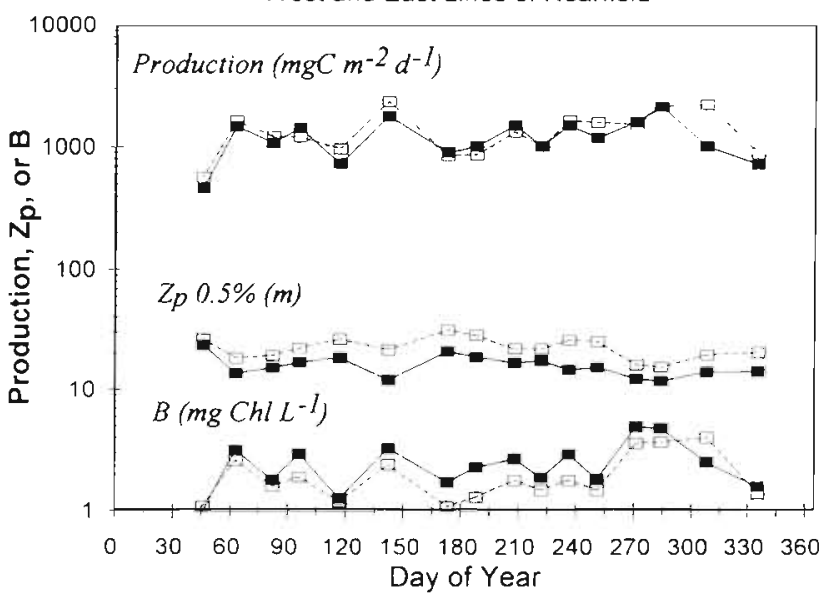

- WEST

Fig. 12. Modeled production for 4 western-edge (shoreward) and 4 eastern-edge (seaward) stations of the nearfield region during 1994. $B$ and $Z_{p}$ terms of the $B Z_{7} I_{0}$ model are shown for each of the west and east station groups. $I_{0}$ did not differ between groups on a given survey, but it varied across surveys (cf. Fig. 10)

\section{Comparison of annual production rates}

Production estimates for the study area (Table 2) were within the range reported for coastal shelf and estuarine systems (e.g Hopkinson 1985, Kelly \& Levin 1986, Nixon 1992). O'Reilly \& Busch (1984) published an extensive compilation of production for shelf waters from the Mid-Atlantic Bight to the Gulf of Maine, finding rates from 280 to $470 \mathrm{~g} \mathrm{C} \mathrm{m}^{-2} \mathrm{yr}^{-1}$ across large geographic sectors. High daily rates were measured in the New York Bight apex area that receives outflow from the Hudson River and nutrients from New York City; Malone (1984) reported production of $590 \mathrm{~g} \mathrm{C} \mathrm{m}^{-2} \mathrm{yr}^{-1}$ for the Hudson River plume extending into coastal shelf water.

Boston Harbor receives a very high nitrogen load, most of which is exported to western Massachusetts Bay, creating a concentration gradient from the Harbor $[\sim 11 \mu \mathrm{M}$ dissolved inorganic nitrogen (DIN) as annual averagel to the eastern side of the nearfield ( 3 HM DIN) (Kelly 1993, 1997). Casting our Harboredge and nearfield production rates in the context of Nixon's (1992, and Nixon et al. 1996) empirical relationship between annual primary production and nitrogen input, it is apparent that coastal ecosystems with commensurate nitrogen input have production in about the same range as the Harbor-western Massachusetts Bay region during 1992-1994 (Fig. 13). Western Massachusetts Bay presently is enriched by export from Boston Harbor and has high primary production. It is interesting that Cape Cod Bay, although less intensively studied, also had high production. Reliable estimates of nitrogen loading to Cape Cod Bay do not exist.

Based on Fig. 13, the Harbor-edge station's annual production range appeared lower than expected. As suggested earlier, Boston Harbor has higher turbidity than the Bay and there may be stronger light limitation of phytoplankton (i.e. a shallow $Z_{p}$ ) in spite of its higher nutrient concentrations (cf. Kelly 1993, Kelly \& Turner 1995b). The Harbor's short water residence time (Signell \& Butman 1992, Kelly 1997), may also contribute to the pattern in Fig. 13, for nutrient inputs have not been normalized for flushing

Table 2. Summary of annual production estimates $\left(\mathrm{g} \mathrm{C} \mathrm{m}^{-2} \mathrm{yr}^{-1}\right)$ for the study area. Text describes derivation of annual results by region

\begin{tabular}{|cccc|}
\hline Year & Nearfield & $\begin{array}{c}\text { Boston } \\
\text { Harbor edge } \\
(1 \text { station })\end{array}$ & $\begin{array}{c}\text { Central } \\
\text { Cape Cod Bay } \\
(2 \text { stations })\end{array}$ \\
\hline 1992 & 386 & 546 & 613 \\
1993 & 620 & 486 & 527 \\
1994 & 468 & 266 & Not measured \\
\hline
\end{tabular}




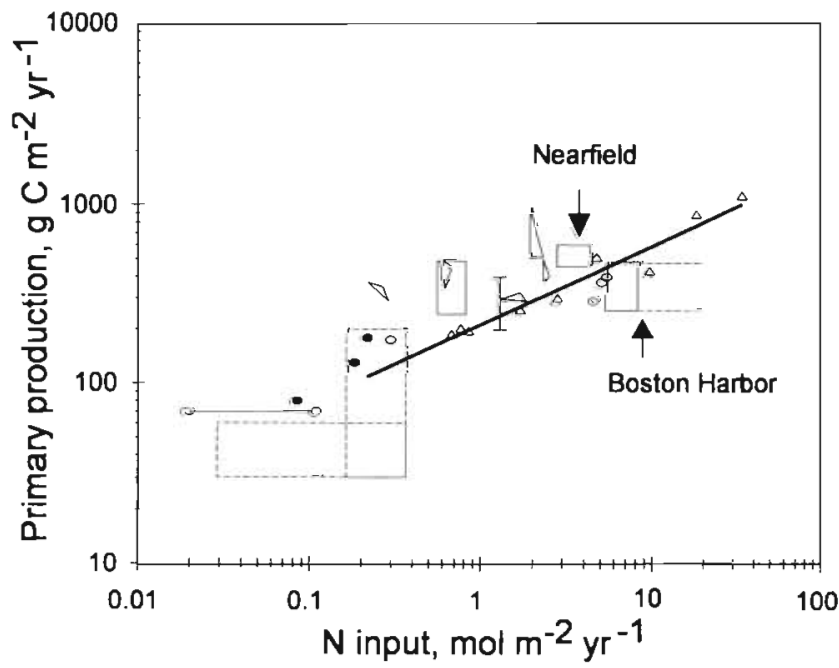

Fig. 13. DIN input and production $\left({ }^{14} \mathrm{C}\right.$ uptake) in different marine and estuarine ecosystems ladapted from Nixon (1992) to include data from this study; see Nixon (1992) for systems and references]. Polygons, rectangles, and solid circles display points or ranges for marine and estuarine systems where land and atmospheric $N$ inputs have been measured, but oceanic inputs have not. Open triangles (from experimental studies in MERL mesocosms) and open circles (shelf and shallow seas) include only situations where total DIN inputs were estimated; Nixon et al. (1996) have included this latter subset of systems in deriving the empirical functional regression relationship shown as the solid line in the figure. Ranges for Boston Harbor and the nearfield region of Massachusetts Bay include only ${ }^{14} \mathrm{C}$ measurements (see Table 2). For Boston Harbor, the solid-line box shows the range of loading (landderived and atmospheric only) for DIN and total N (DIN plus organic forms) as 5.5 to $8.5 \mathrm{~mol} \mathrm{~m}^{-2} \mathrm{yr}^{-1}$ (Kelly 1997). Areal loading at the Harbor-edge station where production was measured is higher, since it is near the present effluent discharge. The dotted lines extend the total DIN input estimate for Boston Harbor by including a very rough estimate of oceanic DIN input $\left(14.8 \mathrm{~mol} \mathrm{~m}^{-2} \mathrm{yr}^{-1}\right)$, calculated as the tidal prism volume (annual) times the adjacent offshore water's

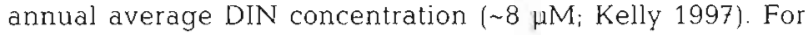
the nearfield of western Massachusetts Bay, Kelly (1993) estimated that $\sim 4.5 \mathrm{~mol}$ total $\mathrm{N} \mathrm{m}^{-2} \mathrm{yr}^{-1}$ or $\sim 3 \mathrm{~mol} \mathrm{DIN} \mathrm{m}{ }^{-2} \mathrm{y}^{-1}$ may be expelled to the surface water in the nearfield region $\left(\sim 100 \mathrm{~km}^{2}\right)$ as export from the Harbor; this must be an underestimate of total inputs because additional inputs from coastal curculation, upwelling, cross-pycnocline exchange, and the atmosphere have not been estimated

\section{CONCLUSIONS}

This is one of the first concerted efforts to use the empirical model construct in a marine monitoring context, a general approach suggested decades ago (Ryther \& Yentsch 1957) and more recently promoted by Cole \& Cloern (1987). The empirical $B Z_{\mathrm{p}} I_{0}$ model developed from Harbor-Bay measurements in 1994 is appropriate as a time-space extrapolation tool, including extrapolation across different years. Each individual measurement will not be predicted accurately by the empirical model - there are sampling and measurement errors in part related to small-scale environmental variability, there is uncertainty regarding the assumptions necessary to convert short-term bottle measurements into integrated production rates, and, moreover, assumptions of the underlying theory may be inapplicable over the entire range of physiological states, plankton communities, physical mixing conditions, and water quality status encountered in nature. However, it is not cost-effective to make incubation measurements at the range of scales required to characterize variable coastal environments; the need for extrapolation and the utility of the $B Z_{p} I_{0}$ model increase as the time-space scales for monitoring broaden. Our study lends strong support to the use of this modeling approach for coastal monitoring studies to provide fundamental information on rates of primary production.

Acknowledgements. Collection of these data and preparation of this paper were supported by the Massachusetts Water Resources Authority (MWRA) under 2 contracts to Battelle Ocean Sciences, Duxbury, Massachusetts. Technical reports containing water quality data during 1992-1994 are available from the MWRA. We thank the field crew at Battelle and the University of Rhode Island (URI) for collecting this extensive series of information and conducting chemical and preliminary data analyses. In particular, Carl Albro, Jack Bechtold, Bob Mandeville, Paul Dragos, Deb West and Scott Libby at Battelle and Edwin Requintina, Laura Reed, Cynthia Heil, and Robert Vaillancourt at URI made substantial contributions to this effort.

\section{LITERATURE CITED}

Bannister TT (1974) Production equations in terms of chlorophyll concentration, quantum yield, and upper limit to production. Limnol Oceanogr 10:1-12

Bender M, Grande K, Johnson K, Marra J, Williams PJLeB, Sieburth J, Pilson M, Langdon C. Hitchcock G, Orchardo J, Hunt C, Donaghay P. Heinemann K (1987) A comparison of four methods for determining planktonic community production. Limnol Oceanogr 32:1085-1098

Borland (1993) User's guide, version 5.0, Quattro Pro for Windows. Borland International, Inc, Scotts Valley, CA 95067-0001

Cole BE, Cloern JE (1987) An empirical model for estimating phytoplankton productivity in estuaries. Mar Ecol Prog Ser 36:299-305

Cote B, Platt T (1983) Day-to-day variations in the springsummer photosynthetic parameters of coastal marine phytoplankton. Limnol Oceanogr 28:320-344

Davies JM, Williams PJleB (1984) Verification of ${ }^{14} \mathrm{C}$ and $\mathrm{O}_{2}$ derived primary organic production measurements using an enclosed ecosystem. J Plankton Res 6:457-474

Falkowski PG (1981) Light-shade adaptation and assimilation numbers. J Plankton Res 3:203-216

Frenette JJ, Demers S, Legendre L, Dodson J (1993) Lack of agreement among models for estimating the photosynthetic parameters. Limnol Oceanogr 38:679-687

Glover HE (1980) Assimilation numbers in cultures of marine phytoplankton. J Plankton Res 2:69-79

Hopkinson CS (1985) Shallow-water benthic and pelagic 
metabolism - evidence of heterotrophy in the nearshore Georgia Bight. Mar Biol 87:19-32

Jassby AD, Platt T (1976) Mathematical formulation of the relationship between photosynthesis and light for phytoplankton. Limnol Oceanogr 21:540-547

Keller AA (1988) Estimating phytoplankton productivity from light availability and biomass in the MERL mesocosms and Narragansett Bay. Mar Ecol Prog Ser 45:159-168

Kelly JR (1993) Nutrients and Massachusetts Bay: an update of eutrophication issues. MWRA Environ Qual Dept Tech Rpt Ser No 93-17. Massachusetts Water Resources Authority, Boston

Kelly JR (1997) Nitrogen flow and the interaction of Boston Harbor with Massachusetts Bay. Estuaries 20(2):in press

Kelly JR, Albro CS, Doering PD, Foster K, Hennessy J, Reed L, Requintina $E$ (1993) Water column monitoring in Massachusetts and Cape Cod Bays: annual report for 1992. MWRA Environ Qual Dept Tech Rpt Ser No 93-16, Massachusetts Water Resources Authority, Boston

Kelly JR, Levin SA (1986) A comparison of aquatic and terrestrial nutrient cycling and production processes in natural ecosystem, with reference to ecological concepts of relevance to some waste disposal issues. In: Kullenberg G (ed) The role of the oceans as a waste disposal option. NATO Advanced Workshop Series, D Reidel Publishing Company, Dordrecht, p 165-203

Kelly JR, Turner JT (1995a) Water column monitoring in Massachusetts and Cape Cod Bays: annual report for 1993. MWRA Environ Quality Tech Rpt Ser No 95-16. Massachusetts Water Resources Authority, Boston

Kelly JR, Turner JT (1995b) Water column monitoring in Massachusetts and Cape Cod Bays: annual report for 1994. MWRA Environ Quality Tech Rpt Ser No 95-17, Massachusetts Water Resources Authority, Boston

Laws EA, DiTullio GR, Carder KL, Betzer PR. Hawes S (1990) Primary production in the deep blue sea. Deep Sea Res 37 . $715-630$

Leftley JW, Bonin DJ, Maestrini SY (1983) Problems in est.mating marine phytoplankton growth, productivity and metabolic activity in nature: an overview of methodology. Ocean Mar Biol Ann Rev 21:23-66

Malone TC (1984) Anthropogenic nitrogen loading and assimilation capacity of the Hudson River estuarine system, USA. In: Kennedy VS (ed) The estuary as a filter Academic Press, Orlando, p 291- 311

Malone TC, Neale PJ (1981) Parameters of light-dependent photosynthesis for phytoplankton size fractions in temperate estuarine and coastal environments. Mar Biol 61:289-297

Natrella MG (1963) Experimental Statistics National Bureau of Standards Handbook 91. US Gov Print Office, Washington, DC

Nixon SW (1992) Quantifying the relationship between nitrogen input and the productivity of marine ecosystems. Pro Adv Mar Tech Conf 5:57-83

Nixon SW, Ammerman JW, Atkinson LP, Berounsky VM,

This article was submitted to the editor
Billen G, Boicourt WC, Boynton WR, Church TM, DiToro DM, Elmgren R, Garber JH, Giblin AE, Jahnke RA, Owens NJP, Pilson MEQ, Seitzinger SP (1996) The fate of nitrogen and phosphorus at the land-sea margin of the North Atlantic Ocean. Biogeochemistry 35:141-180

O'Reilly JE, Busch DA (1984) Phytoplankton primary production on the northwestern Atlantic shelf. Rapp PV Réun Cons Int Explor Mer 183:255-268

Oudot C, Gerard R, Morin P (1988) Precise shipboard determination of dissolved oxygen (Winkler procedure) for productivity studies with a commercial system. Limnol Oceanogr 33:146-150

Oviatt CA, Rudnick DT, Keller AA, Sampou PA, Almquist GT (1986) A comparison of system $\left(\mathrm{O}_{2}\right.$ and $\left.\mathrm{CO}_{2}\right)$ and $\mathrm{C}-14$ measurements of metabolism in estuarine mesocosms. Mar Ecol Prog Ser 28:57-67

Parsons TR, Maita Y, Lalli CM (1984) A manual of chemical and biological methods for seawater analysis. Pergamon Press, Oxford

Peterson BJ (1980) Aquatic primary productivity and the ${ }^{14} \mathrm{C}$ $\mathrm{CO}_{2}$ method: a history of the productivity problem. Ann Rev Ecol Syst II:359-386

Platt T, Gallegos CL, Harrison WG (1980) Photoinhibition of photosynthesis in natural assemblages of marine phytoplankton. J Mar Res 38:687-701

Platt T, Jassby AD (1976) The relationship between photosynthesis and light for natural assemblages of coastal marine phytoplankton. J Phycol 12:421-430

Ricker WE (1973) Linear regressions in fishery research. J Fish Res Bd Can 30:409-434

Ryther JH, Yentsch CS (1957) The estimation of phytoplankton production in the ocean from chlorophyll and light data. Limnol Oceanogr 2:281-286

SAS (1988) SAS procedures guide, release 6.03 edn. SAS Institute, Inc, Cary, NC

Signell RP, Butman B (1992) Modeling tidal exchange and dispersion in Boston Harbor J Geophys Res 97 : 15591-15606

Snedecor GW, Cochran WG (1967) Statistical methods, 6th edn. The lowa State University Press, Ames

Strickland JDH, Parsons TR (1972) A practical handbook of seawater analysis, 2nd edn. Bull Fish Res Bd Can 167

Vollenweider RA (1966) Calculation models of photosynthesis-depth curves and some implications regarding day rate estimates in primary production measurements. In: Goldman CR (ed) Primary production in aquatic environments. Univ of California, Berkeley, p 427-457

Webb WL, Newton M, Starr D (1974) Carbon dioxide exchange of Alnus rubra: a mathematical model. Oecologia 17:281-291

Zimmerman RC, Beeler SooHoo J, Kremer JN, D'Argenio DZ (1987) Evaluation of variance approximation techniques for non-linear photosynthesis-irradiance models. Mar Biol 95:209-215

Manuscript first received: August 6, 1996

Revised version accepted: November 11, 1996 